\title{
IMPLEMENTASI MODEL PEMBELAJARAN PROBLEM BASED INSTRUCTION BERBASIS LKS UNTUK MENINGKATKAN HASIL BELAJAR SISWA PADA KONSEP SISTEM PERNAPASAN KELAS VIII SMP NEGERI 5 AMBON
}

\author{
Yulita Kailola1, F. Leiwakabessy $^{2}$, P.M.J. Tuapattinaya² \\ ${ }^{1}$ Alumni Program Studi Pendidikan Biologi \\ ${ }^{2}$ Staf Pengajar Program Studi Pendidikan Biologi
}

E-mail: lita_kailola@gmail.com

\begin{abstract}
Background: One reason students tend to score below the KKM is the lack of understanding of the material provided by teachers and students less actively involved in the learning process.

Method: This research uses Problem Based Instruction (PBI) model and the Student Sheet (LKS) media. This study looks at the improvement of students' learning outcomes on the concept of the VIII grade system of SMP Negeri 5 Ambon by applying the Problem Based Instruction based LKS model. This research was conducted at SMP Negeri 5 Ambon.

Result: Implementation of Problem Based Instruction based learning model (LKS) based on LKS can improve biology learning result.

Conclusion: Implementation of Problem Based Instruction based learning model can improve student learning outcomes on the concept of Respiratory System of Class VIII4 SMP Negeri 5 Ambon.
\end{abstract}

Keywords: Problem Based Instruction, Student Work Sheet (LKS), Learning Outcomes, Respiratory System.

\begin{abstract}
Abstrak
Latar Belakang: Salah satu penyebab siswa cenderung mendapat nilai dibawah KKM adalah kurang memahami materi yang diberikan oleh guru dan siswa kurang terlibat aktif dalam proses pembelajaran. Metode: Penelitian ini menggunakan model pembelajaran Problem Based Instruction (PBI) dan media Lembaran Kerja Siswa (LKS). Penelitian ini melihat peningkatan hasil belajar siswa pada konsep sistem pernapasan kelas VIII SMP Negeri 5 Ambon dengan menerapkan model pembelajaran Problem Based Instruction berbasis LKS. Penelitian ini dilakukan pada SMP Negeri 5 Ambon.

Hasil: Penerapan model pembelajaran Problem Based Instruction (Pembelajaran Berdasarkan Masalah) berbasis LKS dapat meningkatkan hasil belajar biologi.

Kesimpulan: Penerapan model pembelajaran Problem Based Instruction (Pembelajaran Berdasarkan Masalah) berbasis LKS, dapat meningkatkan hasil belajar siswa pada konsep Sistem Pernapasan kelas VIIII SMP Negeri 5 Ambon.
\end{abstract}

Kata kunci: Problem Based Instruction, Lembaran Kerja Siswa (LKS), Hasil Belajar, Sistem Pernapasan. 


\section{PENDAHULUAN}

Pendidikan di sekolah merupakan kegiatan belajar mengajar yang bertujuan memberikan pengalaman dan pengetahuan kepada siswa. Proses belajar mengajar di sekolah sebaiknya disesuaikan dengan tujuan pembelajaran dan kondisi siswa di kelas, sehingga akan terjadi interaksi siswa dengan guru yang lebih optimal. Variasi model pembelajaran dan kreatifitas guru dapat mengoptimalkan potensi siswa, khususnya pada mata pelajaran yang dianggap sulit dan banyak materi hafalan (Ristanto, 2010). Salah satu masalah pendidikan di Indonesia terletak pada proses pembelajaran yaitu siswa kurang di berikan motivasi untuk mengembangkan kemampuan berpikir dan hanya menerima apa yang diberikan oleh guru mereka. Pembelajaran seperti ini otomatis tidak dapat meningkatkan hasil belajar siswa.

Model pembelajaran berdasarkan masalah merupakan suatu model pembelajaran yang didasarkan pada banyaknya permasalahan yang membutuhkan penyelidikan autentik yakni penyelidikan yang membutuhkan penyelesaian nyata dari permasalahan yang nyata (Trianto, 2007). Menurut Arends dalam Trianto (2011), menyatakan bahwa pengajaran berdasarkan masalah merupakan suatu pendekatan pembelajaran di mana siswa mengerjakan permasalahan yang otentik dengan maksud untuk menyusun pengetahuan mereka sendiri, mengembangkan inkuiri dan keterampilan berpikir tingkat lebih tinggi, mengembangkan kemandirian dan percaya diri.

Lembar Kerja Siswa (LKS) merupakan salah satu perangkat pembelajaran. LKS digunakan guru sebagai alat bantu dalam melaksanakan kegiatan pembelajaran untuk mencapai tujuan pembelajaran dan untuk mengaktifkan siswa. LKS (Lembar Kerja Siswa) adalah sarana berlangsungnya proses pembelajaran yang mengikuti asasasas pembelajaran yang efektif, seperti memberi tekanan pada proses penemuan konsep (LKS sebagai petunjuk mencari tahu) dan mempertimbangkan perbedaan individu sehingga digunakan sebagai strategi (Hidayati, 2012). Konsep yang digunakan dalam penelitian ini adalah materi sistem pernapasan pada manusia. Sehingga siswa dapat mengetahui tentang alat-alat pernapasan manusia serta fungsinya masing-masing, proses pernapasan pada manusia dan kelainan atau penyakit sistem pernapasan pada manusia

\section{MATERI DAN METODE PENELITIAN Jenis Penelitian}

Jenis penelitian ini adalah penelitian deskriptif kuantitatif.

\section{Populasi dan Sampel}

Populasi yang digunakan dalam penelitian ini adalah siswa kelas VIII sebanyak 9 kelas dengan jumlah 249 siswa pada SMP Negeri 5 Ambon. Sampel yang digunakan adalah kelas $\mathrm{VIII}_{4}$. Cara pengambilan sampelnya menggunakan random sampling.

\section{Lokasi dan Waktu Penelitian}

Penelitian ini berlokasi pada SMP Negeri 5 Ambon.Penelitian ini dilaksanakan mulai dari tanggal 26 September 2016 - 26 Oktober 2016.

\section{Analisis Data}

Data yang di peroleh dari penelitian ini kemudian diolah denganmenggunakan analisis data deskriptif (Arikunto, 2010), dengan cara sebagai berikut:

1. Untuk hasil tes butir soal atau tes formatif (aspek kognitif) skor pencapaian di peroleh dengan menggunakan rumus:

Skor pencapaian $=\frac{\text { skor perolehan }}{\text { skor } \text { maksimum }} \times 100 \%$

2. Untuk hasil observasi pada aspek afektif di peroleh dari lembar kerja siswa, dimana siswa dibagi atas beberapa kelompok. Kemudian LKS di bagikan untuk di kerjakan dalam kelompok. Peneliti memberikan nilai sesuai dengan skor yang telah di tentukan. Proses penilaian pada LKS dengan rumus: 
Skor pencapaian $=\frac{\text { skor perolehan }}{\text { skor } \text { maksimum }} \times 100 \%$

3. Untuk hasil observasi pada aspek psikomotor, skor pencapaian di peroleh dengan rumus :

Skor pencapaian $=\frac{\text { skor perolehan }}{\text { skor } \text { maksimum }} \times 100 \%$

4. Untuk nilai proses (NP) di peroleh dengan rumus :

$\mathrm{NP}=\frac{\text { pencapaian kognitif }+ \text { pencapaian afektif }+ \text { pencapaian } \text { psikomotor }}{3}$

5. Untuk memperoleh nilai akhir (NA) baik hasil maupun proses di peroleh dengan rumus:

$$
\begin{aligned}
& \text { NA }=\frac{6 P+4 F}{10} \\
& \text { Keterangan: } \\
& \text { NA : Nilai Akhir } \\
& P \quad: \text { Nilai Proses } \\
& F \quad: \text { Nilai hasil tes formatif setelah proses pembelajaran }
\end{aligned}
$$

\section{HASIL DAN PEMBAHASAN} Hasil

Berdasarkan analisis data yang digunakan, maka hasilnya dapat dipaparkan seperti berikut.Pada bagian ini akan dideskripsikan hasil penelitian nilai tes awal, tes formatif, nilai proses Kegiatan Belajar Mengajar (KBM) dan nilai akhir. Tes awal adalah kegiatan yang dilakukan sebelum proses belajar mengajar dimulai yang bertujuan untuk mengetahui sejauh mana pemahaman siswa mengenai konsep yang akan diajarkan yaitu sistem pernapasan pada manusia. Tes awal ini hanya dilakukan pada pertemuan pertama. Data-data hasil tes awal siswa terlampir pada lampiran 10. Kualifikasi presentase pencapaian hasil tes awal siswa dapat dilihat pada tabel 4.1.

Tabel 1. Kualifikasi Tingkat Penguasaan Siswa Pada Tes Awal

\begin{tabular}{cccc}
\hline Interval & Frekuensi & Presentase (\%) & Kualifikasi \\
\hline$\geq 78$ & - & - & Tuntas \\
$\leq 78$ & 27 & 100 & Gagal \\
Jumlah & $\mathbf{2 7}$ & $\mathbf{1 0 0}$ & - \\
\hline
\end{tabular}

Dari tabel 1 terlihat hasil pencapaian siswa pada tes awal, dimana pada interval $\geq$ 78 belum ada siswa yang mencapai kualifikasi tuntas dan pada interval $\leq 78$ terdapat 27 siswa (100\%) yang berkualifikasi gagal. Berdasarkan hasil penelitian yang dilakukan pada SMP Negeri 5 Ambon, kemampuan kognitif siswa dalam proses pembelajaran dalam hal ini siswa mengerjakan lembaran kerja siswa selama dua pertemuan. Siswa dibagi menjadi 4 kelompok belajar untuk mengerjakan lembaran kerja siswa secara berkelompok. Maka, kualifikasi pencapaian aspek kognitif siswa pada LKS terlihat pada Tabel 4.2 dibawah ini. 
Tabel 2. Kualifikasi Tingkat Penguasaan Siswa Pada Aspek Kognitif (LKS)

\begin{tabular}{llll}
\hline Interval & Frekuensi & Presentasi \% & Kualifikasi \\
\hline $\begin{array}{l}>78 \\
<78\end{array}$ & 27 & 100 & $\begin{array}{l}\text { Tuntas } \\
\text { Gagal }\end{array}$ \\
\hline Jumlah & $\mathbf{2 7}$ & $\mathbf{1 0 0}$ & - \\
\hline
\end{tabular}

Dari tabel 2, hasil belajar siswa pada aspek kognitif dalam hal mengerjakan LKS terlihat pada interval $\geq 78$ sebanyak 27 siswa $(100 \%)$ dapat menguasai indikator pembelajaran dengan kualifikasi tuntas. Penilaian aspek afektif menggunakan lembaran observasi yang disediakan oleh peneliti dengan mencakup 7 aspek penilaian yaitu: kehadiran di kelas, kehadiran dalam kelompok, menghormati pebedaan individu, mendengar dengan aktif, mencari informasi, menerima dengan tanggung jawab, dan menyelesaikan tugas dengan tepat. Penilaian afektif atau sikap siswa dilakukan selama kegiatan proses pembelajaran berlangsung. Data penilaian pada aspek afektif terlihat pada tabel 4.3 di bawah ini.

Tabel 3. Kualifikasi Pencapaian Siswa Pada Aspek Afektif

\begin{tabular}{rlll}
\hline Interval & Frekuensi & Presentase (\%) & Kualifikasi \\
\hline$\geq 78$ & 27 & 100 & Tuntas \\
$\leq 78$ & - & - & Gagal \\
\hline Jumlah & $\mathbf{2 7}$ & $\mathbf{1 0 0}$ & - \\
\hline
\end{tabular}

Dari tabel 3, hasil pencapaian pada aspek afektif terlihat pada interval $\geq 78$ sebanyak $27(100 \%)$ siswa mendapatkan nilai yang baik dengan kualifikasi tuntas dan pada interval $\leq 78$ tidak terdapat siswa dengan kualifikasi gagal.Penilaian aspek psikomotor menggunakan lembaran observasi yang disediakan oleh peneliti dengan mencakup 5 aspek penilaian yaitu : unjuk kerja dalam kelompok, mengkomunikasikan pendapat dan pertanyaan sesuai materi, kerja sama dalam kelompok, terampil dalam memberikan pemecahan masalah, dan memiliki kreativitas. Penilaian psikomotor atau keterampilan siswa dilakukan selama kegiatan proses pembelajaran berlangsung. Data penilaian pada aspek psikomotor terlihat pada tabel 4.4 dibawah ini.

Tabel 4. Kualifikasi Pencapaian Siswa Pada Aspek Psikomotor

\begin{tabular}{cccc}
\hline Interval & Frekuensi & Presentase (\%) & Kualifikasi \\
\hline$\geq 78$ & 27 & 100 & Tuntas \\
$\leq 78$ & - & - & Gagal \\
\hline Jumlah & $\mathbf{2 7}$ & $\mathbf{1 0 0}$ & -
\end{tabular}

Hasil penelitian yang terlihat pada tabel 4 menunjukkan bahwa pada interval $\geq 78$ sebanyak 27 siswa (100\%) mendapatkan nilai dengan kualifikasi tuntas sdan pada interval $\leq 78$ tidak terdapat siswa dengan kualifikasi gagal.Tes akhir (tes formatif) dilakukan pada akhir pertemuan. Tes akhir dilakukan dengan bertujuan untuk mengetahui tingkat penguasaan siswa pada konsep sistem pernapasan pada manusia dengan menerapkan model pembelajaran Problem Based Instruction Bebasis LKS. Maka kualifikasi presentase pencapaian hasil tes akhir (tes formatif) siswa terlihat pada tabel 5 . 
Tabel 5. Kualifikasi Tingkat Penguasan Siswa Pada Tes Akhir (Tes Formatif)

\begin{tabular}{clll}
\hline Interval & Frekuensi & Presentase (\%) & Kualifikasi \\
\hline$\geq 78$ & 27 & 100 & Tuntas \\
$\leq 78$ & - & - & Gagal \\
\hline Jumlah & $\mathbf{2 7}$ & $\mathbf{1 0 0}$ & - \\
\hline
\end{tabular}

Dari hasil penelitian yang tertera pada tabel 5 , menunjukkan bahwa pada interval $\geq 78$ sebanyak 27 orang siswa dapat berhasil memperoleh nilai yang baik dengan kualifikasi tuntas dan pada interval $\leq 78$ tidak terdapat siswa dengan kualifikasi gagal. Nilai akhir yang merupakan hasil belajar siswa dapat diketahui dari presentase tingkat penguasaan siswa pada nilai proses (aspek kognitif,afektif, dan psikomotor) dan presentase penguasaan siswa pada hasil tes akhir (tes formatif). Tingkat penguasaan setiap siswa berbedabeda, ini terlihat dari hasil nilai akhir yang bervariasi. Data kualifikasi pencapaian siswa pada nilai akhir terlihat pada tabel 4.6.

Tabel 6. Kualifikasi Pencapaian Siswa Pada Nilai Akhir

\begin{tabular}{clll}
\hline Interval & Frekuensi & Presentase (\%) & Kualifikasi \\
\hline$\geq 78$ & 27 & 100 & Tuntas \\
$\leq 78$ & - & - & Gagal \\
\hline Jumlah & $\mathbf{2 7}$ & $\mathbf{1 0 0}$ & - \\
\hline
\end{tabular}

Hasil penelitian pada tabel 6 menunjukan bahwa pada interval $\geq 78$ sebanyak 27 siswa memperoleh nilai dengan kualifikasi tuntas sedangkan pada interval $\leq 78$ tidak terdapat siswa dengan kualifikasi gagal.

\section{Pembahasan}

Dalam proses pembelajaran ada 3 aspek penilaian yang dapat digunakan oleh guru untuk mengukur sejauh mana kemampuan siswa memahami materi yang telah diajarkan. Menurut Bloom dalam Latuharhary (2012), ketiga aspek tersebut antara lain : aspek kognitif, afektif dan psikomotor.

\section{Hasil Belajar Pada Aspek Kognitif}

Penilaian pada ranah kognitif ini meliputi tes awal, tes akhir dan mengerjakan Lembaran Kerja Siswa (LKS). Tes awal dan tes akhir dilakukan untuk mengetahui sejauh mana pemahaman siswa mengenai materi sistem pernapasan pada manusia. Hasil dari tes awal dan tes akhir siswa ditentukan tuntas atau tidaknya dilihat dari nilai KKM. Dari hasil penelitian menggambarkan bahwa, tingkat penguasaan materi pada siswa kelas $\mathrm{VIII}_{4}$ SMP Negeri 5 Ambon berada pada kualifikasi tidak tuntas sebanyak 27 siswa (100\%).
Nilai rata-rata pencapaian pada tes awal yaitu 36,96 , dengan nilai yang dicapai tersebut dapat dikatakan bahwa siswa belum mencapai indikator pada konsep sistem pernapasan pada manusia. . Hal ini dapat dimaklumi karena sebagian besar siswa belum memiliki pengetahuan dasar mengenai materi yang diajarkan sehingga hasil belajar yang dicapai menjadi rendah.

Setelah peneliti melakukan proses pembelajaran menggunakan model pembelajaran Problem Based Instruction berbasis LKS, hasil tes akhir siswa menunjukan perbedaan yang signifikan. Dari hasil penelitian, hasil tes akhir menggambarkan bahwa terdapat 27 siswa $(100 \%)$ mampu mencapai nilai yang baik dengan kualifikasi tuntas. Nilai rata-rata yang dicapai pada tes akhir yaitu 85,18. Dengan demikian dapat dinyatakan bahwa siswa telah mencapai ketuntasan belajar pada konsep sistem pernapasan pada manusia. Hal ini dikarenakan siswa dapat terlibat aktif dalam proses pemecahan masalah dan mengerjakan tugas yang diberikan dengan penuh tanggung jawab.

Dengan bekerja secara berkelompok menunjukkan bahwa siswa mampu memecahkan dan menyelesaikan setiap masalah yang terdapat dalam LKS pada 
setiap pertemuan. Berdasarkan pada tabel 2, presentase pencapaian siswa pada aspek kognitif berada pada kualifikasi baik. Dengan demikian siswa dinyatakan berhasil.

Sejalan dengan pendapat Rusman (2011), yang menyatakan bahwa pembelajaran berbasis masalah merupakan inovasi dalam pembelajaran, karena dalam PBI kemampuan berpikir siswa betul-betul dioptimalisasikan melalui proses kerja kelompok atau tim yang sistematis, sehingga siswa dapat memberdayakan, mengasah, menguji, dan mengembangkan kemampuan berpikirnya secara berkesinambungan.

Untuk mengoptimalkan proses pembelajaran, diperlukan kreatifitas guru dalam pemilihan dan penggunaan sumber belajar yang sesuai dengan perkembangan dan kebutuhan siswa. Salah satu bentuk sarana yang mendukung proses pembelajaran adalah Lembar Kegiatan Siswa/LKS (Erryanti \& Poedjiastoeti, 2013). LKS dapat membantu siswa pada saat proses belajar sehingga pembelajarannya menjadi lebih baik dan bermakna (Isnaningsih \& Bimo, 2013) serta membuat prestasi belajar siswa meningkat (Toman, 2013).

\section{Hasil Belajar Pada Aspek Afektif}

Penilaian pada aspek afektif berkaitan dengan sikap siswa selama proses pembelajaran. Berdasarkan pada tabel 3, menunjukan bahwa sebanyak 27 siswa $(100 \%)$ mampu mencapai hasil yang baik dengan skor rata-rata yaitu 95,23. Ketuntasan hasil belajar afektif pada siswa dikarenakan terciptanya suasana yang dapat membangkitkan semangat belajar siswa dan siswa merasa termotivasi untuk memecahkan setiap masalah yang diberikan.

\section{Hasil Belajar Pada Aspek Psikomotor}

Menurut Hamdani (2010), ranah psikomotor adalah berhubungan dengan seluk-beluk yang terjadi karena adanya otototot oleh pikiran sehingga diperoleh keterampilan fisik tertentu. Aspek psikomotor mencakup keterampilan siswa yang berlangsung selama proses pembelajaran. Berdasarkan tabel 4, menunjukkan bahwa skor rata-rata pada aspek psikomotor yaitu 96,57. Berdasarkan jumlah nilai rata-rata pada aspek psikomotor dapat dinyatakan bahwa siswa tergolong dalam kualifikasi tuntas. Keberhasilan ini diperoleh karena siswa serius dan bertanggung jawab dalam memecahkan setiap masalah yang diberikan.

Hasil belajar psikomotor saling berkesinambungan dengan hasil belajar kognitif dan afektif. Hal ini sejalan dengan pendapat yang dikemukakan oleh Sofyan (2006), bahwa hasil belajar psikomotor merupakan kelanjutan dari hasil belajar kognitif dan afektif serta akan tampak setelah siswa menunjukkan perilaku atau perbuatan tertentu sesuai dengan makna yang terkandung pada kedua ranah tersebut dalam kehidupan siswa sehari - hari.

\section{Nilai Akhir}

Nilai akhir dapat berupa angka maupun huruf yang melambangkan keberhasilan siswa. Nilai akhir diperoleh dari nilai proses yaitu nilai kognitif (LKS), afektif, psikomotor dan nilai tes akhir. Hasil nilai akhir tersebut dapat dinyatakan 27 siswa berhasil dengan kualifikasi tuntas dengan nilai rata-rata 89,94 . Hasil penelitian menunjukan bahwa dengan menerapkan model pembelajaran $\mathrm{PBI}$ berbasis LKS dapat memberikan pengaruh yang baik terhadap hasil belajar siswa konsep sistem pernapasan pada manusia.

Pembelajaran dengan model Problem Based Instruction menekankan aktivitas siswa lebih banyak dibandingkan guru melalui pembelajaran antar kelompok dengan pemberian masalah yang berkaitan dengan kehidupan sehari-hari. Selain itu pembelajaran dengan model ProblemBased Instruction siswa dapat saling berbagi pengetahuan dan berusaha menggali informasi secara mandiri serta siswa dipandang sebagai subjek belajar sedangkan guru hanya bertindak sebagai fasilitator dan motivator.

Penerapan model pembelajaran Problem Based Instruction (PBI) berbasis LKS dapat membuat siswa mencapai kriteria ketuntasan minimal (KKM) atau dengan kata lain penerapan model pembelajaran $\mathrm{PBI}$ berbasis LKS dapat meningkatkan hasil belajar siswa pada konsep sistem pernapasan pada manusia. 


\section{KESIMPULAN DAN SARAN \\ Kesimpulan}

Berdasarkan hasil penelitian dan pembahasan, maka dapat disimpulkan bahwa: penerapan model pembelajaran Problem Based Instruction (Pembelajaran Berdasarkan Masalah) berbasis LKS, dapat meningkatkan hasil belajar siswa pada konsep Sistem Pernapasan kelas VIII ${ }^{4}$ SMP Negeri 5 Ambon.

\section{Saran}

Berdasarkan kesimpulan diatas, maka peneliti menyarankan beberapa hal sebagai berikut :

1. Bagi guru biologi, agar sebelum memberikan pelajaran kepada siswa sebaiknya lebih selektif dalam memilih model ataupun media yang akan digunakan yang dapat membuat siswa lebih semangat dan terlibat aktif dalam mengikuti proses pembelajaran sehingga hasil yang dicapai dapat memenuhi kriteria ketuntasan minimal (KKM) yang ditetapkan oleh sekolah tersebut.

2. Bagi peneliti, dapat menggunakan model pembelajaran Problem Based Instruction berbasis LKS untuk diterapkan pada konsep yang lain.

\section{DAFTAR PUSTAKA}

Arikunto, S. 2010. Dasar-dasar Evaluasi Pembelajaran. Jakarta: Bumi Aksara.

Hamdani. 2010. Strategi Belajar Mengajar. Bandung: Pustaka Setia.

Hidayati. 2012. Penerapan Pendekatan Science Teknologi and Society (STS) Sebagai Upaya Meningkatkan Hasil Belajar IPS. Program Studi PGSD Universitas Negeri Yogyakarta.

Latuharhary, J. 2012. Penerapan model pembelajaran mind maping dan jigsaw untuk meningkatkan hasil belajar konsep sistem pernapasan pada siswa kelas VIII SMP Negeri 3 Pulau Haruku. Ambon. Skripsi (Tidak dipubikasikan). Fakultas KIP: Universitas Pattimura.

Ristanto. 2010. Pembelajaran Berbasis Inkuiri Terbimbing dengan Multimedia dan Lingkungan Rill ditinjau dari Gaya Belajar dan Aktivitas Belajar Siswa. Tesis. Program Pascasarjana, Universitas Sebelas Maret: Surakarta
Rusman. 2011. Model-model Pembelajaran. Jakarta: Rajawali Pers.

Sofyan, 2006. Konsep dan Makna Pembelajaran. Bandung : Alfabeta.

Trianto, 2007. Model-model Pembelajaran Inovatif Berorientasi Konstruktivistik. Jakarta: Prestasi Pustaka.

Trianto, 2011. Mendesain Model Pembelajaran Inovatif Progesif Konsep, Landasan dan Implementasi pada Kurikulum Tingkat Satuan Pendidikan (KTSP). Jakarta: Kencana Prenada Media Grup. 